See discussions, stats, and author profiles for this publication at: https://www.researchgate.net/publication/232872526

\title{
The PAH composition in limpets (Patella vulgata L.) from the coasts of Sicily (Italy)
}

Article in Polycyclic Aromatic Compounds · January 2006

DOI: $10.1080 / 10406630500503886$

CITATIONS

18

2 authors:

Antonio Gianguzza

Università degli Studi di Palermo

166 PUBLICATIONS 2,644 CITATIONS

SEE PROFILE

Some of the authors of this publication are also working on these related projects:

Project Management of Sicily aquifers View project
READS

100

Santino Orecchio

Università degli Studi di Palermo

103 PUBLICATIONS 1,544 CITATIONS

SEE PROFILE 
THE PAH COMPOSITION IN LIMPETS (PATELLA VULGATA L.) FROM THE COASTS OF SICILY (ITALY)

\begin{tabular}{ll}
\hline $\begin{array}{l}\text { Antonio Gianguzza } \\
\text { Santino Orecchio }\end{array}$ & \\
\hline & QUERY SHEET
\end{tabular}

Q1: Au: Caption ok?

Q2: Au: Cite in text table 4.

Q3: Au: Au: City?

Q4: Au: Au: City? 
Polycyclic Aromatic Compounds, 26: 1-21, 2006 Copyright (C) 2006 Taylor \& Francis Group, LLC ISSN: 1040-6638 print / 1563-5333 online

DOI: $10.1080 / 10406630500503886$

\section{THE PAH COMPOSITION IN LIMPETS (PATELLA VULGATA L.) FROM THE COASTS OF SICILY (ITALY)}

\section{Antonio Gianguzza \\ $5 \quad$ Santino Orecchio \\ Dipartimento di Chimica Inorganica e Analitica, Università di Palermo, Palermo, Italy}

This article examines the presence, distribution, nature and sources of 19 Polycyclic Aromatic Hydrocarbons (PAH), in

10 Patellae (patella vulgate L.) and seaweed (vulva) sampled in different stations of Sicilian coastal environments and analyzed for their polycyclic aromatic hydrocarbon (PAH) content.

Analysis was performed by gas chromatography/mass

15 spectrometry $(G C / M S)$ with selected ion monitoring (SIM), after saponification of the sample and clean up of the extract. In the limpets the total concentration of polycyclic aromatic hydrocarbons ranged from 34 to $750 \mu \mathrm{g} / \mathrm{Kg}$ of dry matrix. The relative standard deviation (RSD) of the replicas on the concentrations of individual compounds ranged from 4 to $20 \%$. The accuracy of method was estimated by analyzing "blank" samples spiked with known quantities of analytes and the recover percentage was $82 \pm$ $12 \%$. The detection limit ( $L O D)$ of analytical procedure was 25 less than $0.2 \mu \mathrm{g} / \mathrm{Kg}$ d.w. for all analytes. The quantification limit (LOQ) of analytical procedure was less $0.7 \mu \mathrm{g} / \mathrm{Kg} \mathrm{d} . \mathrm{w}$.

The resulting distributions and weight ratios of specific compounds are discussed in terms of sampling location and origin. The results obtained show that levels of contamination vary from one sampling station to the next,

Received 2 July 2005; accepted 10 October 2005.

Address correspondence to Santino Orecchio, Department of Inorganic and Analytical Chemistry, University of Palermo, Parco D'Orleans, Ed. 17, 90128 Palermo, Italy. E-mail: orecchio@unipa.it 
while relative distributions of PAH is homogeneous in most stations. Lipidic content and total PAH concentrations were found not to be correlated and the compounds present in limpets were shown to be mainly of petrogenic origin. There is no evidence of coal-tar contamination.

Keywords environmental chemistry, GCMS, limpet, PAH, Patella vulgata, seaweed

\section{INTRODUCTION}

Polycyclic aromatic hydrocarbons (PAH) are of special concern because of their widespread distribution throughout the environment and their often toxic and carcinogenic properties $(1,2)$. In general, the two main sources of PAH in the environment are fossil fuels, mainly crude oil, and the incomplete combustion of organic materials such as wood, coal and oil. In addition to the many domestic and industrial combustion processes in use today, coal tar containing coating systems are also a major source of PAH in aquatic systems. To these we may add offshore activities, oil spills, offshore installations and shipping exhausts (3). Under anaerobic conditions some PAH can also be derived from biogenic precursors such as pigments and steroids $(4,5)$.

As a consequence of their hydrophobic nature, PAH in aquatic environments rapidly tend to become associated with particulates. Sediments therefore represent the most important reservoir of PAH in the marine environment (6). Some PAH are persistent and toxic to aquatic organisms and can influence the development of liver tumors in several fish species and may adversely affect the reproductive process in fish and other aquatic species.

A practical problem in analyzing environmental contaminants (heavy metals, organic compounds, etc.) in water is the very low concentrations near or below the detectable analytical limits at which they often occur. In water, concentrations vary widely over time, therefore the number of analyses needed for statistical processing is high (7). Interpreting trace contaminants concentrations in water and sediment and predicting the threat they pose to aquatic life under variable physical-chemical conditions is very difficult. The question of bioavailability of PAHs is very complicated and sediment concentrations are a poor guide to the potential toxicity of PAHs to species (8). Bioaccumulators are used to measure contaminant concentrations in aquatic ecosystems through the accumulation of contaminants in their tissues. There are many advantages of 
using organisms. They essentially provide information on the average 70 variation in time and space of the concentrations of contaminants in the surrounding water. Also, they can concentrate the water contamination making the analyses simpler and cheaper.

Generally, for aquatic organisms, the bioaccumulation of lipophilic compounds depends on their concentration in ambient, water and food, on the mechanisms and kinetics that control the distribution between water and food, on the position of the organism in the food chain, on metabolism, and so on $(9,10)$.

Animal and aquatic plants can accumulate hydrocarbons from the environment even when these pollutants are present at very low concentra-

80 tions; thus marine organism have been widely used as bioindicators and integrators of organic pollution in marine ecosystems $(11,12)$. Oysters and limpets have been recommended as indicator organisms. However, recently, Cantillo (13) remarked that oysters and limpets are not equal in their ability to concentrate xenobiotic compounds. In fact, their bioac-

85 cumulation response may be affected by various parameters pertaining to the organism itself as well as those concerned with the environment where the organism is sampled (water temperature, salinity, position in the shoreline, etc.) $(14,15)$.

The Italian marine environment, where strategies for monitoring pol-

90 lution are required, is characterized by a great variety of species. However, the most useful bioindicator organisms (mussels and oysters) do not occur along the Sicilian coast. Consequently, it is necessary to look at other species present in these coastal areas as possible sentinel organisms. The use of new species as possible bioindicators made it necessary

95 to develop research and monitoring strategies simultaneously. The aim of this study is to assess the content and distribution of PAH in the Patella vulgata.

Patella vulgata is a (univalve) gastropod, a soft-bodied invertebrate that is protected by a very hard, flattened conical shell. Limpets cling

100 tightly to a rock (using the muscular foot). Patella vulgata feeds on a wide range of seaweeds. Limpets eat using a radula, a rough tongue-like organ that has thousands of tiny denticles. The biggest limpets are up to $10 \mathrm{~cm}$ wide, but most are smaller. The limpet's shell is not coiled. Limpets may be preyed upon by birds, crabs, starfish and whelks.

105 In this work, limpets (Patella vulgata) from several areas of the Sicilian coasts were sampled and analyzed for their PAH content. Some samples of seaweeds were also analyzed because limpets live in or on the benthos and are grazers feeding on algae.

Potential sources of pollution are well defined in Sicily, as petroleum 110 refinery, dock activities, and some transformation industries can be 
found. In fact, the main parts of human activities in the island are related to agriculture, tourist resorts, and fishing activities localized on the coast. This knowledge makes it easy to know what the main pollutant sources are.

Visual observations made by us have shown the presence of both tar $\mathbf{1 1 5}$ balls and oil slicks around the island and stranded on the beaches, which could be related to the parent crude oils. The increasing power of tourist resources and fishing activities around this island makes necessary the establishment of pollution monitoring programs.

In the present study, investigations were carried out into some PAH $\mathbf{1 2 0}$ identified by the US-EPA as requiring priority monitoring action within the framework of environmental quality control (16). Other non USEPA listed PAH, namely perylene and some methyl derivatives, were also investigated in order to obtain further information on their origins (17-20).

In this work, together with PAH, we analyze water and lipid content because for other matrices it has been demonstrated that the concentrations of PAH in organisms were affected by chemical composition of the matrices such as organic matter and water content (21). Relationships between PAH concentration and distribution, which are useful for evalu- 130 ating possible sources of contamination, were defined by comparing the profiles of $19 \mathrm{PAH}$ compounds recovered from samples.

\section{EXPERIMENTAL PROCEDURE}

\section{Study Site}

Patella vulgata samples were collected at 16 sampling sites (Figure 1), 135 characterized by different human impacts and different hydrodynamic and natural conditions. Sites of sampling were chosen in the Gulfs of Palermo, Catania, Siracusa (Table 1, Figure 1) because of their high concentration of contamination sources, including municipal developments, important trading port and, in the area of Siracusa, some petroleum-plants and oil loading terminals. The Marsala sampling site was taken as reference. Seaweed samples were collected at four sampling sites, referred to as Augusta harbour (2a), Club Nautico (5a), Ortigia (9a), Palermo (12a) (Table 1, Figure 1).

\section{Sampling}

The samples (approx. 30 limpets with a shell length of 3-5 cm) were taken along the shoreline at middle tide through 2003-2004. Efforts 


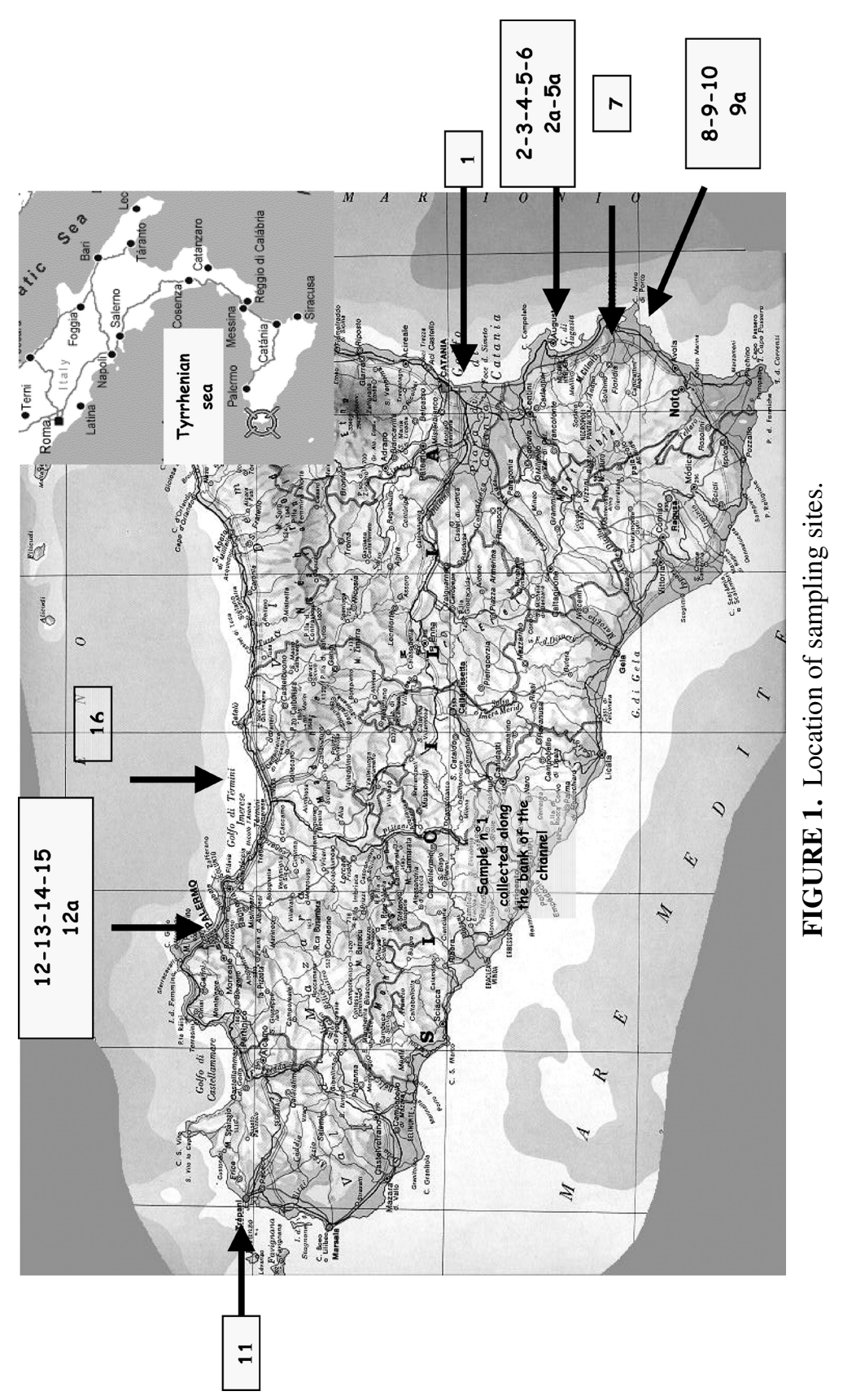


TABLE 1. Characteristics of Sampling Sites

\begin{tabular}{|c|c|c|}
\hline $\begin{array}{l}\text { Station } \\
\mathrm{N}^{\circ}\end{array}$ & Denomination of station & Characteristics of sites \\
\hline 1 & Catania harbor & $\begin{array}{l}\text { On the inside of trading harbor. The main } \\
\text { human influence is due to maritime traffic. }\end{array}$ \\
\hline $2-2 \mathrm{a}$ & Augusta harbor & $\begin{array}{l}\text { On the inside of trading harbor. The main } \\
\text { human influence is due to maritime traffic. }\end{array}$ \\
\hline 3 & Augusta breakwater & On the inside of breakwater. \\
\hline 4 & Augusta breakwater & On the outside of breakwater. \\
\hline $5-5 a$ & Augusta nautical club est & $\begin{array}{l}\text { The main human influence is due to } \\
\text { maritime traffic. }\end{array}$ \\
\hline 6 & Augusta nautical club ovest & $\begin{array}{l}\text { The main human influence is due to } \\
\text { maritime traffic. }\end{array}$ \\
\hline 7 & Priolo & $\begin{array}{l}\text { Is the closest to the industrial area where a } \\
\text { number of chemical industries are } \\
\text { running. }\end{array}$ \\
\hline 8 & Siracusa Targia & $\begin{array}{l}\text { Is assumed to be few contaminated site, } \\
\text { because of the limited human influences } \\
\text { and the strong water exchange with the } \\
\text { sea. }\end{array}$ \\
\hline 9-9A & Siracusa Ortigia harbor & $\begin{array}{l}\text { On the inside of trading harbor. The main } \\
\text { human influence is due to maritime traffic. }\end{array}$ \\
\hline 10 & Siracusa Ortigia harbor & $\begin{array}{l}\text { On the inside of trading harbor. The main } \\
\text { human influence is due to maritime traffic. }\end{array}$ \\
\hline 11 & Marsala & $\begin{array}{l}\text { Is assumed as reference, because of the } \\
\text { limited human influences and the strong } \\
\text { water exchange with the sea. }\end{array}$ \\
\hline $12-12 \mathrm{~A}$ & Palermo F. Italico in & $\begin{array}{l}\text { On the inside of breakwater. Represents an } \\
\text { area characterized by domestic inputs and } \\
\text { maritime traffic. }\end{array}$ \\
\hline 13 & Palermo F.Italico out & $\begin{array}{l}\text { On the inside of breakwater. Represents an } \\
\text { area characterized by domestic inputs and } \\
\text { maritime traffic. }\end{array}$ \\
\hline 14 & Palermo Sperone right-hand & $\begin{array}{l}\text { On the inside of breakwater. Represents an } \\
\text { area characterized by domestic inputs and } \\
\text { maritime traffic. }\end{array}$ \\
\hline 15 & Palermo Sperone left-hand & $\begin{array}{l}\text { On the inside of breakwater. Represents an } \\
\text { area characterized by domestic inputs and } \\
\text { maritime traffic. }\end{array}$ \\
\hline 16 & Cefalù & $\begin{array}{l}\text { Represents an area characterized by light } \\
\text { maritime traffic. }\end{array}$ \\
\hline
\end{tabular}


were made to obtain specimens of homogeneous size at every station but size differences may occur among the stations. Seaweed was manually 150 collected from four stations. The limpet and seaweed samples, wrapped in aluminium foil, were immediately refrigerated $\left(4^{\circ} \mathrm{C}\right)$ on site, stored avoiding exposure to light, and then rapidly transported to the laboratory where they were frozen $\left(-20^{\circ} \mathrm{C}\right)$ less than 6 hours later prior to analysis. Tissues were prepared for analysis by manually removing limpet tissue

155 from their shell and homogenizing it.

\section{Laboratory Equipment}

All glassware and sample containers were thoroughly washed with hot detergent solution followed by rinsing with distilled water and pure acetone respectively. These were finally baked in the oven at $150^{\circ} \mathrm{C}$

160 overnight. To avoid contaminations of samples, different glassware and syringes were used for standards and for solutions extracted from samples.

\section{Chemicals}

All chemicals used were of analytical grade with high purity. In par-

165 ticular, n-pentane and dichloromethane, from Fluka, were $99.8 \%$ pure, ethanol was analytical grade, from Scharlau Chemie S.A. (Barcelona, Spain). Acetone (Envisolv for analysis of dioxins, furans and PCB) from Fluka was $\geq 99.8 \%$ pure. $\mathrm{KOH}$ for trace analysis from Fluka, Standard PAH mixtures (EPA 610 PAH mix, lot LA-96245) and perdeuter-

170 ated internal standards (fortification solution B Lot $\mathrm{N}^{\circ}$ LA-92479) and benz(a)anthracene $d_{12}$ were from Supelco.

Alumina (150 basic, type T particle size $0.063-0.2 \mathrm{~mm}$ ) and silica (Silica gel, particle size 0.063-0.2 mm; Merck, Darmstadt, Germany) were washed with $\mathrm{CH}_{2} \mathrm{Cl}_{2}$ and activated for $14 \mathrm{~h}$ at $150^{\circ} \mathrm{C}$.

\section{Extraction and Clean Up of Limpets}

Quality assurance study was carried out in terms of recovery of PAHs. Some techniques and solvents were tested in order to identify the most efficient extraction procedure (Table 2) because certified samples of patellae for PAHs analysis are not available. Together with the PAH analy-

180 sis, performed on the samples, different recovery tests were carried out by using limpets not containing polycyclic aromatic compounds. These "blank" samples were obtained performing several extraction steps in 48 hours on three samples. After the complete PAH extraction was 
TABLE 2. Results of Recovery Tests Carried out on a Mixture of 19 Compounds

\begin{tabular}{lc}
\hline Extraction method & Recovery \% (mean of three analysis) \\
\hline Soxhlet & $72 \pm 11$ \\
Saponification & $82 \pm 12$ \\
Ultrasound (n-pentane: $\left.\mathrm{CH}_{2} \mathrm{Cl}_{2}=1: 1\right)$ & $61 \pm 13$ \\
Ultrasound $\left(\mathrm{CH}_{2} \mathrm{Cl}_{2}\right)$ & $65 \pm 14$ \\
\hline
\end{tabular}

obtained (checked by GC-MS analysis), a known amount of PAH (EPA) standard mixture was added to each purified "blank" sample. The test 185 samples obtained in this way were extracted using three different methods. The extraction tests, together with the average recoveries, calculated for the compounds investigated, and the relative mean deviations are reported in Table 2. The results favor the saponification method because it allowed us to recover the highest percentage of PAH and are in good 190 agreement with literature data (20).

The internal standard (benz(a)anthracene- $\mathrm{d}_{12}$ ) was added to $1 \mathrm{~g}$ of limpet tissue and the sample was digested for $4 \mathrm{~h}$ under reflux after addition of $50 \mathrm{~mL}$ of an ethanolic solution of $\mathrm{KOH}(2 \mathrm{~mol} / \mathrm{L})$. After cooling, decantation and addition of $20 \mathrm{~mL}$ of water, the digest was liquid-liquid extracted three times with $15 \mathrm{~mL}$ of pentane. The extracts were reduced to a small volume using a rotary evaporator $(\mathrm{T}=35 \pm$ $\left.1{ }^{\circ} \mathrm{C}\right)$.

The purification of the extract was performed by liquid chromatography after dilution with dichloromethane/pentane $(35: 65 \mathrm{v} / \mathrm{v})$ on an 200 alumina micro-column $\left(1.4 \mathrm{~g}\right.$ of $\mathrm{Al}_{2} \mathrm{O}_{3}$, length ca $\left.7 \mathrm{~cm}\right)$. The hydrocarbons were eluted with $8 \mathrm{~mL}$ of dichloromethane/pentane $(35: 65 \mathrm{v} / \mathrm{v})$. The solution was taken up to dryness, diluted with $1 \mathrm{~mL}$ of pentane and then transferred to a silica micro-column $\left(0.8 \mathrm{~g}\right.$ of $\left.\mathrm{SiO}_{2}\right)$. The stationary phase was saturated with pentane, the alkanes were eluted with 205 $2 \mathrm{~mL}$ of pentane and the aromatic fraction was eluted with $5 \mathrm{~mL}$ of the $\mathrm{C}_{2} \mathrm{H}_{2} \mathrm{Cl}_{2} / \mathrm{C}_{5}$ mixture.

The last stage in the procedure involved drying the solution containing PAH under a weak nitrogen flow at room temperature. The dry residue was dissolved in $250 \mu \mathrm{L}$ solution containing the following perdeuterated $\mathbf{2 1 0}$ internal standards in cyclohexane $\left(0.2 \mathrm{mg} / \mathrm{L}\right.$ each): acenaphthene $\mathrm{d}_{10}$; background. phenanthrene $\mathrm{d}_{10}$, chrysene $\mathrm{d}_{12}$ and perylene $\mathrm{d}_{12}$.

To increase the quality of results, every four-five analysis, a blank experiment using uncontaminated water and following all procedures of extraction and cleanup described above was carried out which gave a 215 clean background. 


\section{Lipid Determination}

A Soxhlet extraction procedure was used. About $5 \mathrm{~g}$ of dried limpet tissue were extracted with $50 \mathrm{~mL}$ of Freon (Carlo Erba, Milano) for $4 \mathrm{~h}$. The obtained solution was filtered through a filter containing sodium 220 sulphate and the lipid extract was evaporated to dryness under vacuum. The residue was weighted.

\section{Extraction and Clean Up of Algae}

About $5 \mathrm{~g}$ of sample was treated with precleaned (Soxhlet extracted with dichloromethane for $24 \mathrm{~h}$ ) anhydrous $\mathrm{Na}_{2} \mathrm{SO}_{4}$ (Carlo Erba). A so-

225 lution of a perdeuterated internal standard (benz(a)anthracene- $\mathrm{d}_{12}$ ) was added.

All samples were extracted in a Soxhlet extractor for 24 hours by using the solvent mixture dichloromethane-pentane 1:1 (Carlo Erba, Milano). The extracts were filtered through pre-cleaned Pasteur's pipette

230 filled with solvent-rinsed glass wool and pre-cleaned anhydrous $\mathrm{Na}_{2} \mathrm{SO}_{4}$, rinsed and concentrated in a rotary evaporator with the thermostatic bath at $\mathrm{T}=35 \pm 1{ }^{\circ} \mathrm{C}$. The final volume was around $5 \mathrm{~mL}$. Finally, the solution containing PAH was taken to dryness under a weak nitrogen flow. The dry residue was dissolved in $0.5 \mathrm{~mL}$ solution con-

235 taining the following perdeuterated internal standards in cyclohexane $(0.2 \mathrm{mg} / \mathrm{L}$ each $)$ : Acenaphthene $\mathrm{d}_{10}$; Phenanthrene $\mathrm{d}_{10}$, Chrysene $\mathrm{d}_{12}$ and Perylene $\mathrm{d}_{12}$.

\section{PAH Analysis}

PAH were analyzed with a Shimadzu gas chromatograph-mass spec240 trometer (GC-MS mod. GC-17A quadrupole detector GCMS-QP5000) equipped with a capillary Equity-5 $(30 \mathrm{~m} \times 0.25 \mathrm{id}, 0.5 \mu \mathrm{m})$ column from Supelco (Milano, Italy) and a splitless injector (0.61 $\mathrm{min})$. The gas carrier was $\mathrm{He}$ at a flow rate of $1.4 \mathrm{ml} \mathrm{min}^{-1}$. The injector was heated at a temperature of $280^{\circ} \mathrm{C}$; the column temperature was $40^{\circ} \mathrm{C}$ for $2 \mathrm{~min}$,

245 then it was raised to $100^{\circ} \mathrm{C}$ at $40.0^{\circ} \mathrm{C} \mathrm{min}{ }^{-1}$, to $200^{\circ} \mathrm{C}$ at $10^{\circ} \mathrm{C} \mathrm{min}-1$, to $325^{\circ} \mathrm{C}$ at $30^{\circ} \mathrm{C} \mathrm{min}^{-1}$ and kept for $8 \mathrm{~min}$. The detector was seated at $250^{\circ} \mathrm{C}$. The total run time was about $35 \mathrm{~min}$. The spectrometer was used in selected ion monitoring mode (SIM).

Identification of the components of the standard mixture was carried 250 out by comparing retention times for each component in the mixture with those of pure components analyzed under the same experimental conditions. Identification was confirmed by comparing the spectra of the 
single components with those stored in the acquisition system library. The identification of PAH in the solutions extracted from limpets and seaweeds was carried out on the basis of previously determined retention 255 times and confirmed using mass spectra.

The PAH content in the sample was quantified relatively to the perdeuterated PAH added to the dry residue. The response factors for different compounds were measured by injecting, every two days, a mixture containing standard compounds and having the same concentration of $\mathbf{2 6 0}$ perdeuterated PAH as that used for spiking the sample. The most abundant ion was used for quantification and two other ions were additionally used for confirmation. Selected ion chromatogram of a patella vulgata extract is given in Figure 2.

\section{Water Content Analysis}

About $2 \mathrm{~g}$ of homogenized sample (limpets or seaweeds) was dried at $105^{\circ} \mathrm{C}$ for one night. The water content was determined by weight loss and was utilized to correlate all the results with dry weight.

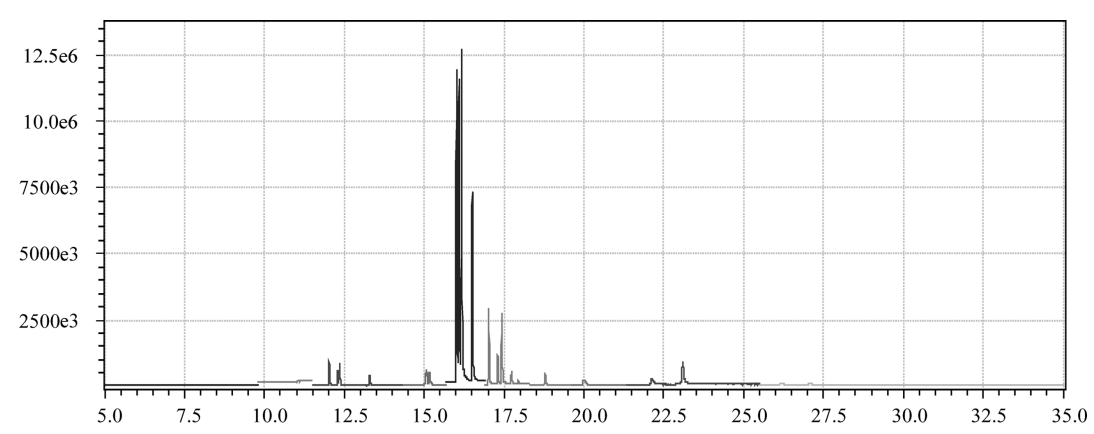

(a)

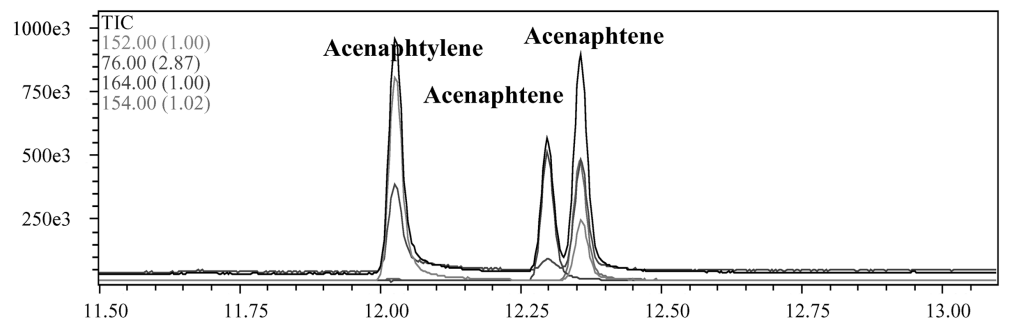

(b)

FIGURE 2. (a) Select ion monitoring chromatogram of a limpet extracted.

(b) Chromatogram of three components of a limpet extracted. 


\section{RESULTS AND CONCLUSIONS}

270 Extraction yields, utilizing perdeuterated internal standard (benz(a)anthracene- $\mathrm{d}_{12}$ ) was never less than $70 \%$ and in most cases almost $100 \%$.

In Table 3 are reported the average of three independent measurements for individual and total concentrations of $\mathrm{PAH}$, water and lipid content detected in limpet and seaweed samples.

275 To evaluate the precision of the analysis, three replicates of field samples (limpets and seaweeds) were analyzed. For the limpets, the relative standard deviation (RSD) of the replicas on the concentrations of individual compounds ranged from 4 to $20 \%$, while for the seaweed ranged from 7 to $18 \%$.

280 The detection limit (LOD), estimated as $3 \sigma$ (three times the background noise) (IUPAC criterion), was similar for all analyzed compounds and results less than $0.2 \mu \mathrm{g} / \mathrm{Kg}$ d.w. for all analytes. The blank values of analytical procedure remained always below the quantification limit (LOQ): $0.7 \mu \mathrm{g} / \mathrm{Kg}$ d.w., estimated as 10 times $\sigma$.

285 For the limpets, the total concentration of the 22 compounds investigated, expressed as the sum of concentrations, $\Sigma \mathrm{PAH}$, varies from 34 to $750 \mu \mathrm{g} / \mathrm{Kg}$ of dry matrix. The wide range of PAH concentrations found in the limpets indicates heterogeneous levels of contamination. This can be explained by considering the different level of contamination of the 290 sites.

The highest PAH concentrations have been measured in stations $\mathrm{n}^{\circ}$ 2, 1 (Augusta Harbor, Catania Harbor) and $\mathrm{n}^{\circ} 4$ (Augusta breakwater). The high concentrations of PAH recorded at stations corresponding to harbors are due to the petroleum contamination (in some cases roughly

295 manifest) in the considered sites. Station $\mathrm{n}^{\circ} 4$, located at Augusta, represents an area characterized by domestic inputs and maritime traffic. These stations probably represent localized sites of high contamination and do not reflect the concentrations found in the remainders of areas.

300 The concentrations of PAH in limpets close to pollution sources $\left(\mathrm{n}^{\circ} 2\right.$, $1,4)$ had high concentrations compared to limpets sampled away from point sources and in reference station $\left(\mathrm{n}^{\circ} 11\right)$ located at Marsala. This evidence is in good agreement with results of Baumard (23) who suggested that away from pollution sources there was a threshold below which or-

305 ganisms balanced the uptake and depuration of PAH thus maintaining a relatively constant concentration.

The concentration of carcinogen PAH in the samples of patella vulgata ranged from 0.8 to $240 \mu \mathrm{g} / \mathrm{Kg}$ d.w. expressed as benzo(a)pyrene $(24,25)$ (Figure 3). 


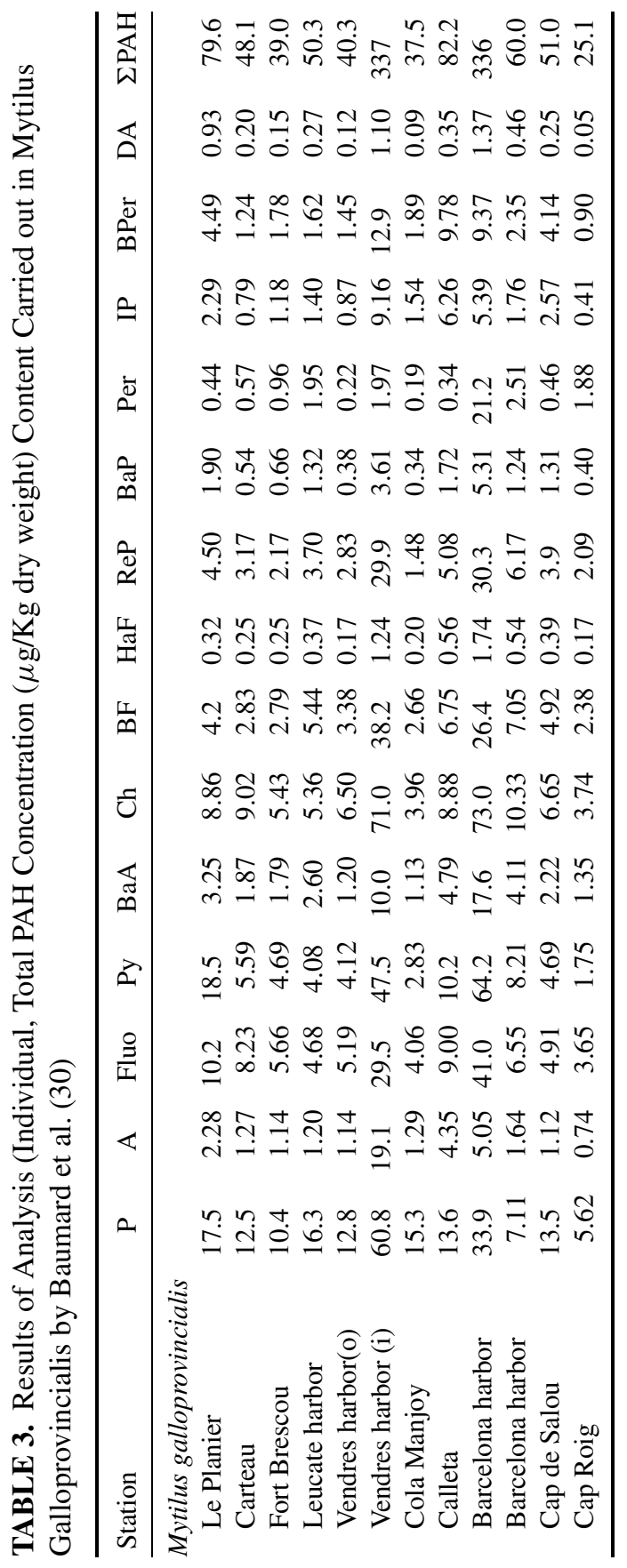




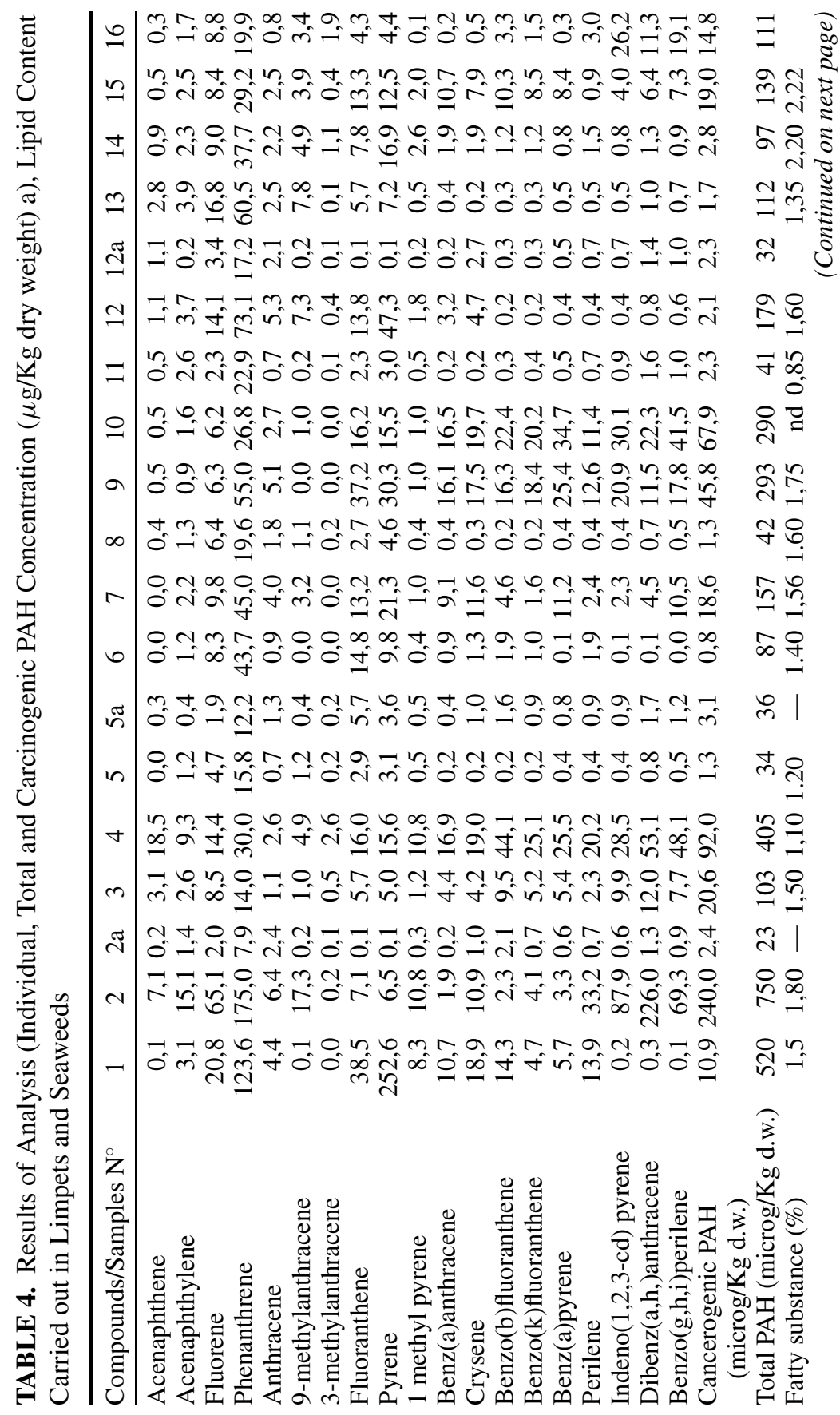


Polycyclic Aromatic Compounds $\quad$ TFJD365-03-150371 January 11, 2006 18:9

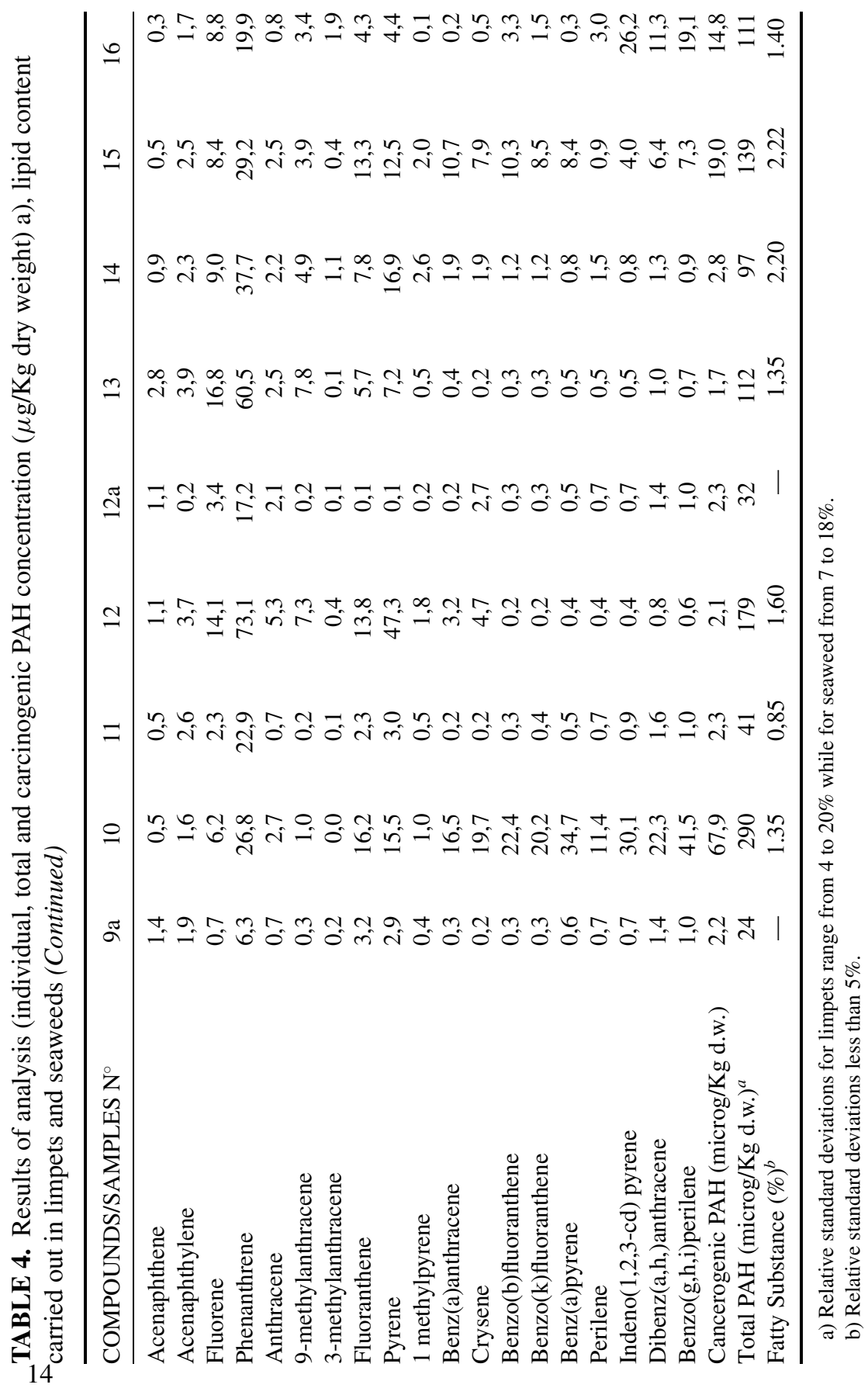




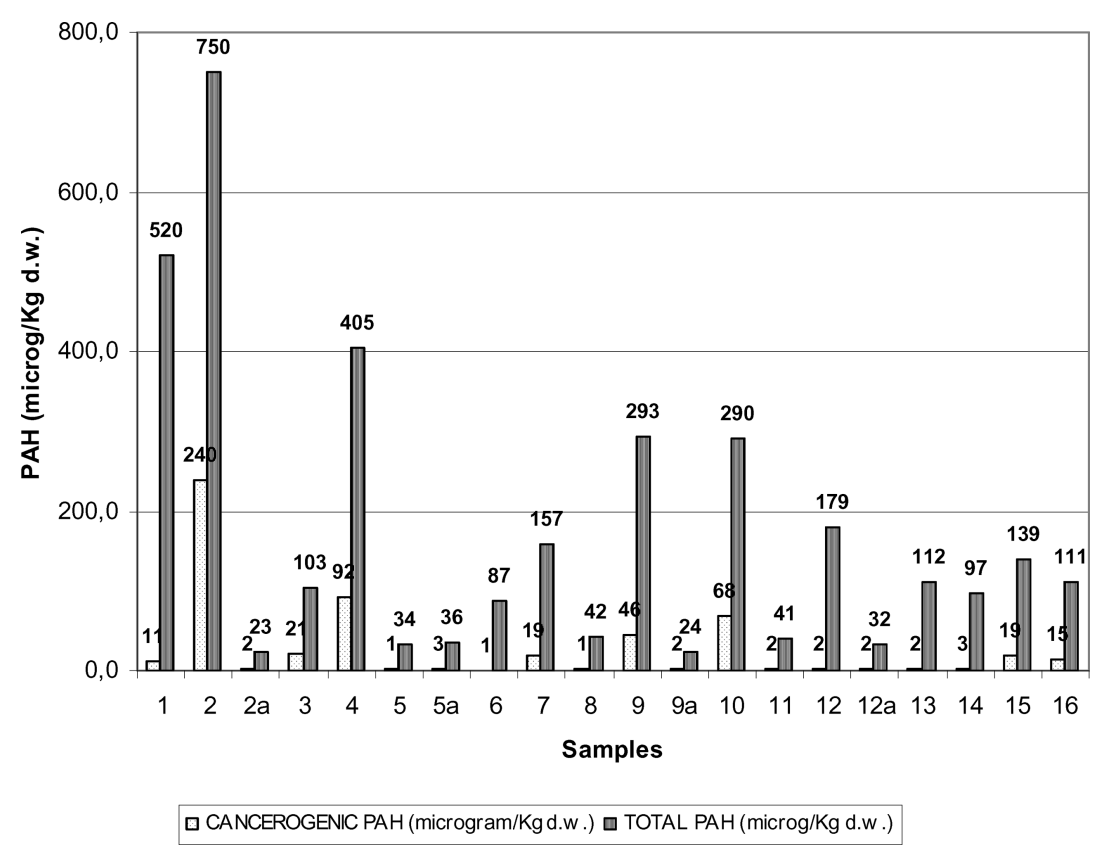

FIGURE 3. Total and carcinogenic PAH concentration ( $\mu \mathrm{g} / \mathrm{Kg}$ dry weight).

310 For the seaweeds, the total concentration of the 19 compounds investigated varies from 23 to $36 \mu \mathrm{g} / \mathrm{Kg}$ of dry sample and, practically, shows no distinct spatial trends. These low and nearly constant concentrations constitute an apparent baseline level, which is through the result from equilibrium between uptake and depuration of the absorbed PAH.

315 In most of the sampling sites, the same distribution of PAH (expressed as weight percentage) is observed. Phenanthrene, Fluoranthene and Pyrene are the three most abundant components in nearly all the samples.

In Table 3, as comparison, are shown the PAHs concentrations 320 recorded on bivalves (Mytilus galloprovincialis) sampled on European coasts and analysed by Baumard et al. (23). In this case PAH concentrations ranged from 25 to $337 \mu \mathrm{g} / \mathrm{Kg}$ d.w. The mussels, filter-feeding organisms, were mainly exposed to the soluble fraction of PAHs. Therefore, they accumulate the bio available fraction of the contaminants present in 325 the water column (dissolved and particulate PAHs and the compounds present in the plankton and the PAH content of their tissues reflect the profile of the compounds they have been exposed to).

The accumulation of contaminants in the limpets may be either indirectly caused by stimulation of the animal's feeding and metabolic 
activities, or by an increased uptake of contaminated food particles. 330 Limpets are a food source for other species; in fact, directly or indirectly the presence of the pollutants in their tissues may be a risk for potential bioaccumulation in the food.

For the limpets, the lipid content is in the range from 0.85 to $2.2 \%$. With the aim to find a relationship between the lipid content and the $\mathbf{3 3 5}$ concentration of total PAHs determined in samples investigated, we carried out a linear regression analysis. The results show that there is no correlation of considered parameters.

Some processes can generate polycyclic aromatic compounds. What makes it difficult to accurately identify PAH origins is the fact that there exist a number of possible sources and processes that analytes can undergo prior to absorption in seaweeds and limpets.

The molecular patterns generated by each source, however, are like fingerprints, which make it possible to hypothesize which processes generate PAH by studying their distribution in samples. Pyrolytic sources $\mathbf{3 4 5}$ are characterized by the presence of PAH over a wide range of molecular weights, while petrogenic sources are dominated by the lowest molecular weight $\mathrm{PAH}$.

The presence of low molecular weight compounds is typically from spill-associated hydrocarbons (24), while pyrogenic polycyclic aromatic $\mathbf{3 5 0}$ hydrocarbons are generally characterized by the dominance of high molecular mass PAH over those with low molecular mass (25).

If we group polycyclic aromatic compounds into different classes depending on the number of aromatic rings present in their structure, it can be observed (Figure 4) that the PAH with 2,3 and 4-rings found $\mathbf{3 5 5}$ in Patella vulgata samples at the sites under investigation constitute from 44 to $98 \%$ of the total, while for the seaweed ranged from 82 to $88 \%$.

However a preferential accumulation of the lower molecular weight and more water soluble PAH was observed. Thus, limpets accumulated $\mathbf{3 6 0}$ preferentially phenanthrene, the most soluble PAH measured, but also the tetra-aromatic $\mathrm{PAH}$, compounds that are present in great abundance in petroleum. These evidences suggest that PAH contamination in the limpets and in the seaweeds might originate mainly from the pollution caused by the petrogenic sources.

In our stations, limpets were located on piers of jetty with high water depth, far from the sediment and the seaweeds and are exposed to the petroleum contamination present in the upper part of the water column and/or deposited on surface of rocks. The occurrence of petroleum on the surface of the water may often be observed by the diffraction of the $\mathbf{3 7 0}$ sun light. 


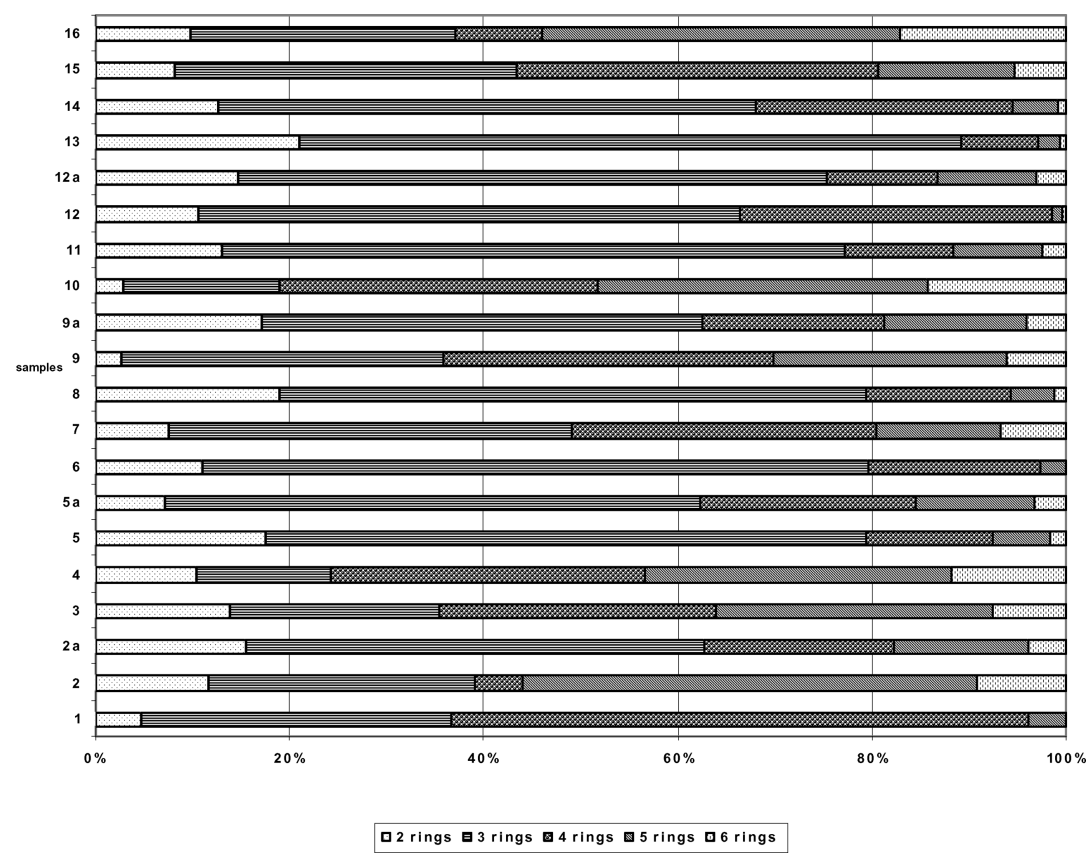

FIGURE 4. Contribution of 2,3,4,5 and 6 rings to total PAH.

Further, sources of PAH pollution in the aquatic ecosystems under investigation were estimated by comparing the distribution indexes of some polycyclic aromatic compounds with their concentration ra375 tios. Supposing that patellae, likewise mussels, are characterized by low biotransformation capacities (23) compared to vertebrates, PAH ratios used in marine sediments we use for marine invertebrates (patellae). Phenanthrene/anthracene and fluoranthene/pyrene ratios have commonly been used as a means of determining the main origins of PAH $380(19,28,29)$.

Phenanthrene and anthracene are both structural isomers. In particular, phenanthrene is more thermodynamically stable than anthracene; therefore, in petrogenic $\mathrm{PAH}$ pollution the $\mathrm{Ph} / \mathrm{An}$ ratio is very high, while high temperatures during the combustion process favor the formation of 385 anthracene and a lowering of the $\mathrm{Ph} / \mathrm{An}$ ratio. Because of the differences in reactivity and solubility of these two pairs of isomers, their respective ratios are not expected to remain constant and cannot, therefore, provide a picture of the progress of PAH from their origins, through environmental transport, to uptaking in marine organisms. In particular, a ratio of $390 \mathrm{Phe} / \mathrm{Ant}<10$ and Flu/Py $>1$ indicated a contamination due to pyrolytic 


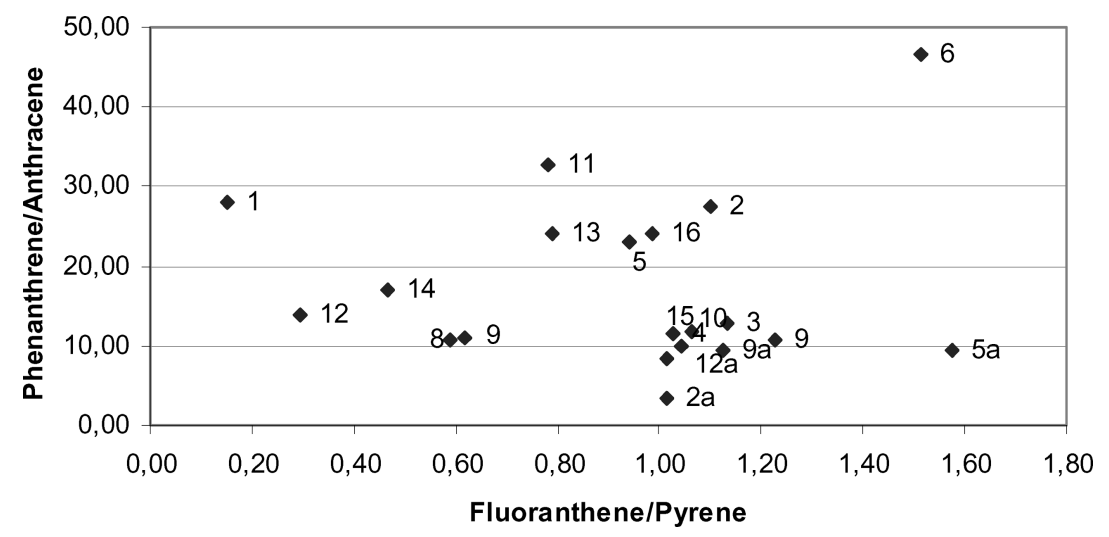

FIGURE 5. Plot of ratio Phenanthrene/Anthracene $v s$. ratio Fluoranthene/Pyrene.

origin (30). Figure 5 shows values of these ratios calculated for limpets and seaweeds samples.

The plot suggests that PAH in the limpets are mainly of petrogenic origin while in the seaweeds there is a small contribute of pyrolytic origin. Additionally, it is reported in literature (29) that a phenanthrene/anthracene ratio of about four is typical of urban areas, while larger ratios were more common for remote locations. The average ratio for all the sites investigated in this work was 19.7 for limpets and 7.6 for seaweed, which are consistent with the relative long distance of urban site from the sampling stations.

Total methylated PAH ranged from 0.4 to $8.9 \%$ of total PAH. The highest methylated PAH concentrations have been measured in samples of limpets of stations $\mathrm{n}^{\circ}$ 14, 13, 12 (Palermo Sperone, Palermo Foro Italico, Augusta Nautical Club). The higher concentrations of substituted $\mathrm{PAH}$ are recorded at stations corresponding to areas devoted to maritime activities and are due to the petroleum contamination (in some cases roughly manifest). Some authors stated that different sources will give mixtures with quite different relative amounts of unsubtituted $\mathrm{PAH}$ compared to their alkyl homologues and La-Flamme and Hites (30) report that high temperatures $\left(\approx 2200^{\circ} \mathrm{K}\right)$ will yield soot devoid of alkyl $4 \mathbf{4 1 0}$ PAH. Lower temperatures $\left(\approx 1100^{\circ} \mathrm{K}\right)$ will yield quite abundant substituted compounds, while extended periods of time ( $10^{6}$ years) at low temperatures $\left(\approx 430^{\circ} \mathrm{K}\right)$ will yield $\mathrm{PAH}$ mixtures in which alkyl $\mathrm{PAH}$ dominate (as in petroleum).

Our main remarks are as follows:

1. The present study made it possible to optimize extraction and analytical conditions for the determination of PAH in patella. Under these 
conditions, recoveries are very good: never less than $70 \%$ and in most cases almost $100 \%$. Reproducibility is also satisfactory (relative stan-

420 dard deviation ranged from 4 to $20 \%$ ).

2. The use of an Equity-5 column allowed complete separation in a shorter space of time (about $30 \mathrm{~min}$ ) than proved possible in previous studies on PAH $(6,32)$. The results reported here represent the first quantitative investigations of PAH in patella vulgate of Mediterranean area.

3. The greater presence of PAH with low molecular weights (2-4 rings) in all samples and the $\mathrm{Ph} / \mathrm{An}$ and $\mathrm{Fl} / \mathrm{Py}$ ratio values used as $\mathrm{PAH}$ distribution indexes demonstrate that most samples owe their PAH to a predominant single origin, i.e., petroleum product.

430 4. Total PAH content in limpet samples were not correlate with PAH concentrations of seaweeds collected in the same place.

5. There is no evidence of coal-tar contamination; for coal-tar the Fl/Py ratio is $\geq 1.5$ and this ratio is lower for limpets collected.

6. Total PAH concentrations in the limpets were not correlated with lipid content.

\section{REFERENCES}

1. E. J. Hoffman, G. L. Mills, J. S. Latimer, and J. G. Quinn, Urban Runoff as a Source of Polycyclic Aromatic Hydrocarbons to Coastal Waters, Environmental Science and Technology 18 (1984):580-587.

440 2. R. J. Pruell and J. G. Quinn, Geochemistry of Organic Contaminants in Narragansett Bay Sediments, Estuarine Coastal and Shelf Science 21 (1985):295312.

3. M. Howsam and K. C. Jones, Sources of PAH in the Environment, in The Handbook of Environmental Chemistry-PAH and Related Compounds, vol. 3-I (1998):137174, (Springer).

4. S. G. Wakeham, C. Schaffner, and W. Giger, Perylene in Sediments from the Namibian Shelf, Geochimica et Cosmochimica Acta 43 (1979):1141-1144.

5. S. G. Wakeham, C. Schaffner, and W. Giger, Polycyclic Aromatic Hydrocarbons in Recent Lake Sediment-II. Compounds Derived from Biogenic Precursors during Early Diagenesis, Geochimica et Cosmochimica Acta 44 (1980):415-429.

6. A. Giacalone, A. Gianguzza, M. R. Mannino, S. Orecchio, and D. Piazzese, Polycyclic Hydrocarbons in Sediments of Marine Coastal Lagoons in Messina, Italy: Extraction and GC/MS Distribution and Sources, Polycyclic Aromatic Compounds, 24(2), (2004):135-149.

455 7. J. Koistinen, Sirpa S. Herve, M. Lahtiperä, and J. Paasivirta, Chloroaromatic Pollutants in Mussels Incubated in Two Finnish Watercourses Polluted by Industry, Chemosphera 34(12) (1997):2553-2569.

8. P. Somerfield, M. Gee, and R. M. Warwick, Benthic Community Structure in Relation to an Instantaneous Discharge of Wastewater from a Tin Mine, Mar. Pollut. Bull. 28(6) (1994):363-369. 
9. N. Kannan, T. B. H. Reusch, D. E. Shulz-Bull, G. Petrick, and J. C. Duinker, Chlorobiphenyls: Model Compounds for Metabolism in Food Chain Organisms and Their Potential use as Ecotoxicological Stress Indicators by Application of the Metabolic Slope Concept, Environ. Sci. Technol 29 (1995):1851-1859.

10. M. I. Dassenakis, M. A. Kloukiniotu, and A. S. Pavlidon, The Influence of Long $\mathbf{4 6 5}$ Existing Pollution on Trace Metal Levels in a Small Tidal Mediterranean Bay, Mar. Poll. Bull. 22 (1996):275-282.

11. P. W. Kwan and R. C. Clark, Assessment of Oil Contamination in Marine Environment by Pattern Recognition Analysis of Parafinic Hydrocarbon Content of Limpets, Anal. Chim. Acta 133 (1981):151-168.

12. P. Baumard, P. Garrigues Budzinski, J. F. Narbonne, T. Burgeot, X. Michel, and J. Bellocq, Polycyclic Aromatic Hydrocarbon (PAH) Burden of Limpets (Mytilus Sp.) in Different Marine Environments in Relation with Sediment PAH Contamination, and Bioavailability, Marine Environmental Research 47 (1999):415-439.

13. A. Y. Cantillo, Comparison of Results of Mussels Watch Programs of the United $\mathbf{4 7 5}$ States and Frame with Worldwide Mussel Watch studies, Mar. Poll. Bull. 36 (1998): 712-717.

14. D. J. H. Phillips, Quantitative Aquatic Biological Indicators, Applied Pu. Ltd, London: (1980).

15. E. Mendez, M. S. Astorga Espana, and F. J. Garcia Montelongo, Polycyclic Aromatic Hydrocarbons and n-alkanes in the Intertidal Limpet Patella Crenata from the Coast of Tenerife (Canary Islands), Bull. Environ. Contam. Toxicol. 63 (1999):665672.

16. B. R. T. Simoneit, Biomarker PAH in the Environment in The Handbook of Environmental Chemistry - PAH and Related M Compounds, vol. 3-I, (1998):175-222, (Springer)

17. S. Sportsol, N. Gros, R. G. Lichtenthaler, K. O. Gustavsen, K. Urdel, F. Ordel, and J. Skel, Source Identification of Aromatic Hydrocarbons in Sediments Using GC/MS, Environmental Science and Technology, 17 (1983):282-286.

18. J. C. Colombo, E. Pelletin, C. Brochn, M. Khall, and A. Catoggio, Determination of 490 Hydrocarbon Distribution Indexes-Case Study: Rio de la Plata estuary, Argentina, Environmental Science and Technology, 23 (1989):888-894.

19. H. Budzinski, I. Jones, J. Bellocq, C. Piérard, and P. Garrigues, Evaluation of Sediment Contamination by Polycyclic Aromatic Hydrocarbon in the Gironde Estuary, Marine Chemistry, 58 (1997):85-97.

20. Irwin J. Roy, Environmental Contaminants Encyclopedia, www.nature.nps.gov/ hazardssafety/toxic//, (1998).

21. G. B. Kim, K. A. Maruja, R. F. Lee, J. H. Lee, C. H. Koh, and S. S. Tanabe, Distribution and Sources of Polycyclic Aromatic Hydrocarbons in Sediments from Kyeonggi Bay, Korea, Marine pollution Bulletin 28 (1999):166-169.

22. D. R. Oros and J. R. M. Ross, Polycyclic Aromatic Hydrocarbons in San Francisco Estuary Sediment, Marine Chemistry 86 (2004):169-184.

23. P. Baumard, H. Budzinski, P. Garrigues, J. C. Sorbe, T. Burgeot, and J. Bellocq, Concentrations of PAHs in Various Marine Organisms in Relation to Those in Sediments and to Trophic Level, Marine Pollution Bulletin 36 (1998):951-960. 
505 24. P. R. Mc Clure, Evaluation of a Component-based Relative Potency Approach to Cancer Risk Assessment for Exposure PAHs. Poster presented at the Annual Meeting of the Society of Toxicology, Anaheim California, March 11, 1996, on

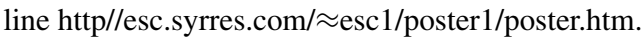

25. C. Minoia and L. Perbellini, Monitoraggio Ambientale e Biologico dell'Esposizione

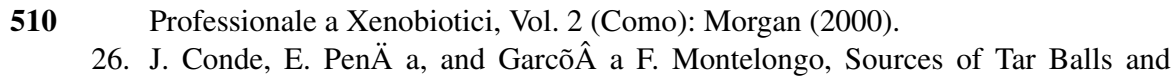
Oil Slicks on the Coasts of the Canary Islands, Inter. J. Environ. Anal. Chem. 62 (1996):77-84.

27. G. Witt, Polycyclic Aromatic Hydrocarbons in Water and Sediments of the Baltic Sea, Marine Pollution Bulletin 36 (1998):577-586.

515

28. P. M. Gschwend and R. A. Hites, Fluxes of the Polycyclic Aromatic Hydrocarbons to Marine and Lacustrine Sediments in the Northeastern United States Geochimica et Cosmochimica Acta 45 (1981):2359-2367.

29. N. Ohkouchi, K. Kawamura, and H. Kawahata, Distributions of Three- and Seven Rings Polynuclear Aromatic Hydrocarbons on the Deep Sea Floor in Central Pacific, Environ. Sci. Technol. 33 (1999):3086-3090.

30. R. E. LaFlamme and R. A. Hites, The Global Distribution of Polycyclic Aromatic Hydrocarbons in Recent Sediment, Geochim. Cosmochim. Acta, 42 (1978):289303.

525 31. C. Y. Raoux and P. Garrigues, Mechanism Model of Polycyclic Aromatic Hydrocarbons Contamination of Marine Coastal Sediments from the Mediterranean Sea. P. In Garrigues, \& M. Lamotte (Eds.), Proceedings of the 13th international syposium on polynuclear aromatic hydrocarbons; Bordeaux, France 1-4 October, 1991 (pp. 443-450). (Langhorn, PA: Gordon \& Breach publishers).

530 32. L. Culotta, M. R. Melati, and S. Orecchio, The use of Leaves of Rosmarinus officinalis L. as Samplers for Polycyclic Aromatic Hydrocarbons, Assessment of Air Quality in the Area of Palermo, Ann. Chim. (Rome) 92 (2002):837-845. 